\title{
Relevansi Industri 4.0 dan Society 5.0 Terhadap Pendidikan Di Indonesia
}

\author{
Felixtian Teknowijoyo ${ }^{1}$, Leni Marpelina ${ }^{* 2}$ \\ f.teknowijoyo@student.uns.ac.id*1, lenimarpelina@gmail.com ${ }^{2}$ \\ Ilmu Pendidikan*1 ${ }^{1}$, Pendidikan Sejarah ${ }^{2}$ Universitas Sebelas Maret
}

Received: November 2021

Accepted: November 2021

Online Published: Desember 2021

\begin{abstract}
This research aims to analyze the industrial revolution 4.0 and 5.0 and its relevance to education in Indonesia. Research methods using literature studies that review or critically review the knowledge, ideas, or findings contained in journals, books, and other scientific works The results of research show that the presence of the industrial revolution 4.0 and 5.0 contributed significantly to Indonesian education. One of them is the existence of technology-based learning innovations that make it easier for students to learn without knowing space, time, and place. Industry 4.0 is technology-driven, society 5.0, however, is valuedriven. The former requires the latter to remind society's essential needs, values, and responsibilities as the primary target; The latter requires the former for a technological push and solution. Therefore, the development of the Industrial Revolution 4.0 and 5.0 is expected to bring progress to the development of education, especially in Indonesia, by creating change and preparing superior and innovative graduates with skills that have been prepared in advance.
\end{abstract}

Keywords: Industry 4.0, Society 5.0, Education

\begin{abstract}
Abstrak
Penelitian ini bertujuan untuk menganalisis revolusi industri 4.0 dan 5.0 serta relevansinya terhadap pendidikan di Indonesia. Metode penelitian menggunakan studi literatur yakni mengkaji atau meninjau secara kritis pengetahuan, gagasan, atau temuan yang terdapat dalam jurnal, buku maupun karya ilmiah lainnya. Untuk menelusuri konsep Industri 4.0 dan Society 5.0 maka langkah utama adalah mengidentifikasi istilahistilah kunci, tinjauan literatur awal dilakukan dengan mencari istilah "Industri 4.0" dan "Society 5.0" di Google Scholar. Hasil penelitian menunjukkan bahwa kehadiran revolusi industri 4.0 dan Society 5.0 mempunyai relevansi terhadap pendidikan di Indonesia. Karena baik industri 4.0 maupun Society 5.0 menekankan pada kesiapan untuk mengembangkan kreativitas dan berpikir kritis, hal ini sejalan dengan tujuan pendidikan di Indonesia. Kehadiran revolusi industri 4.0 dan 5.0 memberikan kontribusi besar terhadap pendidikan Indonesia. Salah satunya adalah adanya inovasi pembelajaran yang berbasis teknologi yang memudahkan siswa dalam belajar tanpa mengenal ruang,waktu dan tempat. Oleh karena itu perkembangan revolusi Industri 4.0 dan 5.0 diharapkan membawa kemajuan bagi pengembangan pendidikan khususnya di Indonesia dengan menciptakan perubahan dan menyiapkan lulusan yang unggul dan inovatif dengan skill yang sudah dipersiapkan sebelumnya.
\end{abstract}

Kata Kunci : Industri 4.0, Society 5.0, Pendidikan 


\section{PENDAHULUAN}

Beberapa tahun terakhir, laju perkembangan teknologi kecerdasan buatan (Artificial Intelligence) telah dipercepat dan digunakan secara global sehingga sangat mempengaruhi berbagai industri, infrastruktur, sosial, dan aktivitas manusia lainnya. Perkembangan teknologi yang sangat pesat tersebut menyebabkan perubahan nilai masyarakat. Nilai baru yang diciptakan oleh perkembangan teknologi disebut industry 4.0 dan society 5.0.

Menyikapi perkembangan pesat di era Revolusi Industri 4.0, negara-negara mulai melakukan berbagai langkah. Sebagai negara maju di bidang teknologi, Jepang memimpin dalam pengusulan konsep Society 5.0. Konsep ini diharapkan dapat memperkuat United Nations Sustainable Development Goals, yaitu mengentaskan kemiskinan, melindungi planet ini, dan menjamin kemakmuran bagi semua (Shiroishi, Y., Uchiyama, K., Suzuki, 2018). Konsep Social 5.0 sebenarnya merupakan konsep yang sangat panjang. Konsep ini muncul dalam " Basic Economic and Fiscal Policy ".

Society 5.0 merupakan era yang merepresentasikan keadaan masyarakat saat ini karena hadir di Industri 4.0, artinya teknologi sudah menjadi bagian dari kehidupan masyarakat. Di satu sisi, sulit untuk mengatakan bahwa Jepang cukup kompetitif dalam teknologi kecerdasan buatan. Perkembangan dunia teknologi saat ini mengharuskan semua lembaga termasuk pendidikan mulai dari sekolah dasar hingga perguruan tinggi haruslah turut menjawabnya. Sejarah mencatat hanya orang-orang yang cerdas yang mampu membaca sprit zaman (zeitgeist) yang mampu bertahan dan dikenang setiap zamannya sesuai dengan perkembangan dan dinamika yang mengiringinya (Farid Ahmadi,H.I 2020)

Pendidikan memainkan peran yang sangat penting dalam perbaikan kualitas sumber daya dalam standar kehidupan sosial yang terus berkembang di dunia/masyarakat global. Sistem pendidikan yang tepat membawa kemajuan bagi suatu negara. Eksistensi suatu bangsa dapat eksis melalui kontribusinya terhadap peradaban dunia. Sehingga Pendidikan terus menyesuaikan serta menyelaraskan dengan kemajuan teknologi (Fahrezi, 2021). Unsur-unsur pemikiran dan peradaban sosial yang maju merupakan salah satu keniscayaan peradaban bangsa yang besar. Perbedaan nilai dalam adat, budaya, bahasa, dan sistem kepercayaan tidak menjadi masalah, karena nilai dasar yang dijadikan pedoman setiap negara biasanya berdampak positif bagi manusia (Falaq, 2020). Nilai-nilai dasar tersebut adalah nilai-nilai kemanusiaan, yaitu nilai-nilai universal (Pahlevi, 2016). Oleh karena itu penelitian ini berusaha untuk menelusuri industry 4.0 dan society 5.0 serta relevansinya terhadap pendidikan di Indonesia.

\section{METODE PENELITIAN}

Penelitian ini merupakan studi literatur dengan jenis penelitian kualitatif deskriptif dengan kajian kepustakaan (library research) yang berusaha mengambarkan relevansi industri 4.0 dan society 5.0 terhadap pendidikan di Indonesia. Tinjauan pustaka bertujuan untuk mengidentifikasi aspek-aspek sentral dari Industri 4.0 dan society 5.0 agar dapat 
memperoleh definisi istilah ini yang dapat diterima baik oleh peneliti maupun praktisi (Cooper, 1998). Untuk membuat konsep Industri 4.0 dan Society 5.0 maka langkah utama adalah mengidentifikasi istilah-istilah kunci, tinjauan literatur awal dilakukan dengan mencari istilah "Industri 4.0" dan "Society 5.0" di Google Scholar. Pada penelitian studi literatur ini penulis menggunakan berbagai sumber tertulis seperti artikel, jurnal dan buku yang relevan dengan kajian dalam penelitian ini.

\section{HASIL DAN PEMBAHASAN}

\section{HASIL}

\section{A. Konsep Industri 4.0}

Revolusi Industri Keempat (alias Industri 4.0, diterjemahkan dari Industri 4.0 seperti dalam bahasa Jerman) bermula tahun 2011 dari sebuah proyek dalam strategi teknologi tinggi pemerintah Jerman. Ini memajukan konsep Cyber Physical Systems (CPS) VogelHeuser \& Hess, (2016) menjadi Cyber Physical Production Systems (CPPS). SmartFactory adalah salah satu inisiatif terkait utama Industri 4.0 (Zuehlke, 2010). Istilah Industri 4.0 diperkenalkan secara publik pada tahun 2011 di Hannover Fair.

Industri 4.0 merupakan inisiatif strategis nasional yang dipimpin oleh Kementerian Pendidikan dan Penelitian (BMBF) dan Kementerian Perekonomian dan Energi (BMWI). Untuk merundingkan prakarsa tersebut, dibentuklah kelompok kerja yang terdiri dari aktoraktor dari pemerintah serta dari dunia usaha dan universitas. Kelompok kerja dipimpin oleh Henning Kagermann, mantan ketua SAP SE dan presiden Akademi Sains dan Teknik Jerman (acatech). Pada bulan April 2013, kelompok kerja mengeluarkan rekomendasinya dalam sebuah laporan berjudul "Rekomendasi untuk mengimplementasikan inisiatif strategis industri 4.0. (Wegener, K., Kunz, A., Bochmann, L., \& Bänziger, 2016)

Menurut laporan tersebut, pabrik pintar harus menggunakan perangkat IoT dan Internet untuk mengumpulkan data pada semua tahap proses produksi di ruang fisik (dunia nyata), dan kemudian membuat ulang data ini di dunia maya. Artificial Intelligence kemudian menganalisis data cyber ini, atau menjalankan simulasi untuk mendapatkan solusi optimal. Temuan Artificial Intelligence akan secara otomatis dimasukkan kembali ke dalam sistem kontrol pabrik dunia nyata. Sederhananya, pabrik pintar adalah pabrik yang berpikir sendiri (Hitachi-Tokyo Laboratory, 2018).

Hermann et al., (2015) menguraikan prinsip industry 4.0 terdiri dari empat desain. Pertama, koneksi merupakan kapasitas mesin, gadget, sensor, dan manusia untuk saling berinteraksi satu sama lain dengan penggunaan Internet of Things (IoT) atau Internet of People (IOP). Akan tetapi prinsip ini memerlukan kolaborasi, keamanan, dan standar. Kedua, transparansi informasi mengacu pada kemampuan sistem informasi untuk membangun replika virtual dari dunia nyata dengan memasukkan data sensor ke dalam model digital (termasuk analisis data dan penyediaan informasi). 3. Bantuan untuk masalah 
teknis, seperti; (a) sistem bantuan mendukung kemampuan orang dalam mengambil keputusan dan memecahkan permasalahan secepat mungkin dalam waktu yang sangat singkat dengan cara menggabungkan dan mengevaluasi informasi; mendukung kemampuan orang untuk melakukan tugas yang tidak aman; (b) termasuk visi dan fisik pendampingan. Keempat, pengambilan keputusan terpusat atau kemampuan sistem fisik virtual untuk membuat keputusan dan menyelesaikan tugas seefektif mungkin tanpa campur tangan manusia.

Namun, kemunculan Industri 4.0 menjadi ancaman bagi dunia yang semakin kompetitif. Kehadiran robot yang semakin cerdas lambat laun akan mengambil alih peran manusia, sehingga secara berangsur peran manusia akan hilang dengan sendirinya. Ancaman ini mengharuskan pemerintah dan seluruh masyarakat harus memiliki kemampuan lebih untuk dapat mengatasi hal tersebut khusnya pada bagian pendidikan. Namun jika pemerintah Indonesia gagal dalam mengatasi kondisi tersebut makan masyarakat akan kalah bersaing dengan robot. Tentunya hal tersebut akan mengakibatkan angka pengangguran semakin tinggi (Farid Ahmadi, 2020)

\section{B. Konsep Society $\mathbf{5 . 0}$}

Menyikapi revolusi industri 4.0 yang semakin pesat, negara-negara di dunia mulai melakukan Langkah-langkah strategis. Jepang, sebagai salah satu negara yang mempunyai kemajuan di bidang teknologi, mengajukan konsep society 5.0. Konsep tersebut bertujuan untuk memperkuat pembangunan berkelanjutan perserikatan bangsa-angsa harapanya untuk mengakhiri kemiskinan, melindungi planet, dan memastikan kemakmuran bagi semua manusia (Shiroishi, Y., Uchiyama, K., Suzuki, 2018).

Perdana Menteri Jepang Shinzo Abe mengusulkan visi baru Jepang untuk society 5.0 atau masyarakat super cerdas pada tanggal 23 Januari 2019, pada pelaksanaan pertemuan tahunan Forum Ekonomi Dunia di Davos, Swiss. Society 5.0 adalah masyarakat yang berpatokan pada manusia yang mampu melakukan keseimbangan terhadap kemajuan ekonomi dan memecahkan masalah sosial melalui proses integrasi sistem ruang virtual dan fisik.

Salgues (2018) memberikan definisi terhadap society 5.0 yaitu sebagai sebuah masyarakat cerdas yang mengintegrasikan lingkungan nyata (fisik) dan lingkungan virtual (jaringan). Selain itu Kepa, J K., Unamuno, G., Urkia, E., Serna, (2019) juga berpendapat yang menyebutkan bahwa teknologi merupakan pelaku utama dalam keberlangsungan revolusi Industri 4.0 di mana ICT (teknologi informasi dan komunikasi) terintegrasi penuh pada sist em produksi. Sedangkan society 5.0 pusatnya adalah manusia, seperti yang disampaikan Alhefeiti, (2018), society 5.0 berupaya untuk menjadi teknologi yang berpusat pada manusia (human-centric society) yang terintegrasi penuh antara dunia maya dan nyata. Disisi lain Raharja (2019) menunjukkan bahwa society 5.0 masih erat kaitannya 
dengan Industri 4.0, namun teknologi di society 5.0 lebih mengarah pada tatanan kehidupan sosial masyarakat.

Society 5.0 berpusat pada tiga nilai inti yang saling berhubungan: berpusat pada manusia, keberlanjutan, dan ketahanan. Pendekatan yang berpusat pada manusia menempatkan kebutuhan dan kepentingan inti manusia di jantung proses produksi, bergeser dari kemajuan yang didorong oleh teknologi ke pendekatan yang sepenuhnya berpusat pada manusia dan berpusat pada masyarakat (Xu et al., 2021). Akibatnya, pekerja industri akan mengembangkan peran baru sebagai pergeseran nilai dari menganggap pekerja sebagai "biaya" menjadi "investasi". Teknologi adalah untuk melayani manusia dan masyarakat, artinya teknologi yang digunakan dalam manufaktur adaptif dengan kebutuhan dan keragaman pekerja industri (Lu et al., 2021). Lingkungan kerja yang aman dan inklusif harus diciptakan untuk memprioritaskan kesehatan fisik, kesehatan mental dan kesejahteraan, dan pada akhirnya melindungi hak-hak dasar pekerja, yaitu otonomi, martabat manusia, dan privasi.

Society 5.0 bertujuan untuk menciptakan konsep masyarakat yang peduli pada kemanusiaan, melalui pertumbuhan ekonomi dan penyelesaian masyarakat, semua tantangan diharapkan dapat diatasi, sehingga setiap fase masyarakat dapat menikmati kualitas hidup yang aktif dan nyaman (M. Fukuyama, 2018). Kebutuhan integrasi masyarakat society 5.0 terdiri dari 1) kebijakan inovasi, 2) jiwa wirausaha, dan 3) keterampilan wirausaha.

\section{Perbedaan Industri 4.0 dan Society 5.}

\begin{tabular}{|c|c|c|}
\hline Judul & Industrie 4.0 (Germany) & Society 5.0 (Japan) \\
\hline$\theta_{0}$ & $\begin{array}{l}\text { - Rencana aksi strategi teknologi tinggi } \\
2020 \text { untuk Jerman (BMBF, 2011) }\end{array}$ & $\begin{array}{l}\text { - Rencana dasar sains teknologi ke } 5 \\
\text { (released 2016) }\end{array}$ \\
\hline$\frac{\mathscr{n}}{\underline{a}}$ & $\begin{array}{lr}\text { - Rekomendasi } & \text { untuk } \\
\text { mengimplementasikan } & \text { inisiatif } \\
\text { strategis industri 4.0 } & \text { (Industrie } 4.0 \\
\text { Working Group, 2013) } & \end{array}$ & $\begin{array}{l}\text { - Strategi komprehensif sains, untuk } \\
\text { teknologi dan inovasi } 2017 \text { (released } \\
\text { 2017) }\end{array}$ \\
\hline 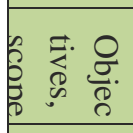 & $\begin{array}{l}\text { - Pabrik Pintar } \\
\text { - Berfokus pada manufaktur }\end{array}$ & $\begin{array}{l}\text { - Masyarakat super cerdas } \\
\text { - Masyarakat secara keseluruhan }\end{array}$ \\
\hline 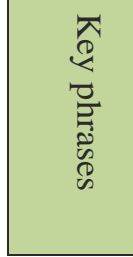 & $\begin{array}{l}\text { - Cyber-physical systems (CPS) } \\
\text { - Internet of Things (IoT) } \\
\text { - Penyesuaian massal }\end{array}$ & $\begin{array}{l}\text { - Konvergensi tingkat tinggi dari dunia } \\
\text { maya dan ruang fisik } \\
\text { - Menyeimbangkan pembangunan ekonomi } \\
\text { dengan penyelesaian masalah sosia. } \\
\text { - Berpusat pada manusia }\end{array}$ \\
\hline
\end{tabular}

Gambar 1. Industri 4.0 vs. Masyarakat 5.0

Sumber : (Hitachi-Tokyo Laboratory, 2018)

Industri 4.0 dianggap sebagai revolusi berbasis teknologi untuk mencapai efisiensi dan produktivitas yang lebih tinggi dan, sebagai strategi teknologi tinggi pemerintah, untuk 
meningkatkan daya saing Jerman di pasar global. Perbedaan yang cukup besar dalam ruang lingkup efek masa depan yang dimaksudkan dari inovasi teknologi (Xu et al., 2021). Industri 4.0 menyerukan revolusi industri yang berpusat pada manufaktur, tetapi tidak mengatakan apapun tentang bagaimana revolusi semacam itu dapat berdampak pada publik. Sebaliknya, seperti yang diilustrasikan oleh konsep masyarakat yang berpusat pada manusia, society 5.0 sangat berfokus pada dampak publik dari teknologi dan pada kebutuhan untuk menciptakan masyarakat yang lebih baik. Termasuk dalam cakupan visi society 5.0 adalah program reformasi yang dimaksudkan untuk menghasilkan masyarakat inklusif yang melayani berbagai kebutuhan dan preferensi.

Industri 5.0 melengkapi paradigma Industri 4.0 yang ada dengan memiliki penelitian dan inovasi yang mendorong transisi ke industri Eropa yang berkelanjutan, berpusat pada manusia, dan tangguh (Breque, M., De Nul, L., \& Petridis, 2021). Jelas bahwa Industri 5.0 dihasilkan dari konsensus Komisi Eropa tentang perlunya mengintegrasikan prioritas sosial dan lingkungan Eropa dengan lebih baik ke dalam inovasi teknologi dan mengalihkan fokus dari teknologi individual ke pendekatan sistematis. Dengan pengakuan bahwa kemajuan teknologi mengubah cara nilai diciptakan, dipertukarkan, dan didistribusikan, ada kebutuhan mendesak agar teknologi ini dirancang untuk mendukung nilai-nilai masyarakat di masa depan.

Pada kondisi awal informasi sosial, metode yang paling umum digunakan untuk mengumpulkan informasi melalui internet dan menganalisisnya secara manual. Namun di society 5.0, manusia, mesin, dan sistem semuanya berinteraksi di dunia virtual, dan hasil terbaik yang dihasilkan oleh kecerdasan buatan melampaui kemampuan manusia untuk kembali ke alam fisik. Proses ini membawa nilai baru bagi industri dan masyarakat dengan cara yang berbeda. Gagasan society 5.0 adalah visi pemerintah Jepang untuk masyarakat masa depan. Pemerintah Jepang mengungkapkan bahwa era industri 4.0 lebih memperhatikan proses manufaktur, sedangkan masyarakat 5.0 lebih memperhatikan inovasi dengan manusia sebagai pusatnya (people oriented, dalam hal ini meningkatkan kualitas hidup, tanggung jawab sosial dan pembangunan berkelanjutan melalui pemanfaatan kemajuan teknologi tersebut (Sumarno, 2019). Hal ini seperti terdapat pada gambar 2.

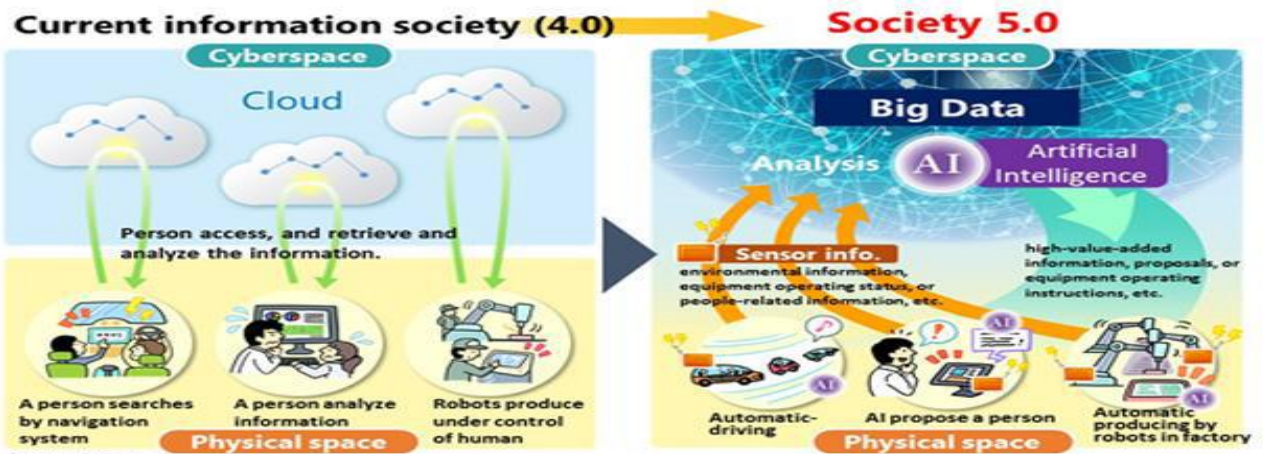

Gambar 2. Informasi Terkini 4.0 Dan 5.0

Sumber : (Sajidan et al., 2021) 
Pada dasarnya revolusi industri dan society 5.0 mampu meningkatkan kualitas hidup manusia. Jadi apabila berbicara tentang kualitas layanan, pemerintah harus dapat menciptakan sumber pelayanan dan keamanan untuk manusia seperti tujuan society 5.0 yang berpusat pada manusia itu sendiri.

\section{Relevansi Industry 4.0 dan Society 5.0 Terhadap Pendidikan di Indonesia}

Sebagai penggerak Revolusi Industri 4.0, teknologi informasi dan komunikasi akan terus bergulir dan mengalami perkembangan yang sangat cepat. Di era industri 4.0 dan society 5.0 teknologi informasi berkembang pesat, menambah warna kehidupan setiap orang. Era revolusi industri 4.0 diawali dengan berkembangnya Internet of Things, dan kini telah merambah ke segala bidang kehidupan masyarakat. Sedangkan society 5.0 mengubah konsep teknologi big data yang dikumpulkan oleh Internet of Things (IoT) dari Artificial Intelligence (AI) menjadi sesuatu yang dapat membantu orang meningkatkan kehidupan manusia (Xu et al., 2021).

Internet of things (IoT) yang merambah pada semua aspek kehidupan mengubah cara pandang masyarakat Indonesia, termasuk bidang pendidikan. Pendidikan 4.0 adalah konsep yang diciptakan oleh para ahli teori pendidikan yang mewakili berbagai pendekatan untuk mengintegrasikan teknologi jaringan ke dalam kelas. Perkembangan globalisasi di Indonesia masih dalam era 4.0 (Lu et al., 2021). Era 4.0 yang telah berjalan di Indonesia sejak tahun 2011 sedikit banyak telah mengubah peran guru. Menurut Muhadjir Effendy (Mendikbud) yang dikutip oleh Yusnaini, (2019) bahwa menembus era 4.0 dalam dunia pendidikan dibutuhkan perbaikan kurikulum dengan meningkatkan kompetensi siswa, meliputi 1) Berpikir kritis; 2) Kreativitas dan inovasi; 3) Keterampilan interpersonal dan komunikasi; 4) Teamwork dan kolaborasi; 5) Percaya diri (Falaq, 2020).

Di era revolusi industri 4.0 lembaga pendidikan berada pada posisi yang ideal untuk membantu menumbuhkan tenaga kerja yang ideal dan unggul. Siswa dapat mengakses informasi yang tersedia tanpa batas, menjadikannya pilihan untuk pembelajaran virtual dan terhubung dengan mudah karena terintegrasi ke berbagai platform. Selain itu pembelajaran di era revolusi 4.0 dapat menerapkan blended learning dan case-based learning.

Pendidikan 4.0 merupakan rencana perluasan akses dan relevansi untuk mendukung terwujudnya smart education melalui peningkatan dan pemerataan mutu pendidikan serta pemanfaatan teknologi untuk mewujudkan pendidikan kelas dunia guna menumbuhkembangkan peserta didik yang memiliki keterampilan abad ke-21 yang mengacu pada standar kompetensi global yang mempersiapkan generasi muda untuk memasuki dunia kerja dan realitas kehidupan di abad ke-21.

Pendidikan tidak lagi berpusat pada hubungan timbal balik atau dua arah antara siswa dan guru, tetapi pada jaringan sebagai pusatnya, secara langsung menghubungi siswa lain dengan sumber informasi yang berbeda; tidak hanya di dalam negeri, tetapi juga di luar negeri. Hal ini mendorong pengembangan metode dan konsep pembelajaran yang lebih 
individual, kemandirian siswa dan metode perolehan pengetahuan pribadi akan terlaksana dengan baik. Inilah yang disebut dengan era pendidikan 4.0 (Shiroishi, Y., Uchiyama, K., Suzuki, 2018).

Bahkan pada masa pendidikan society 5.0 memungkinkan siswa akan belajar berdampingan bersama robot sebagai pengganti guru. Dalam menghadapi tantangan era society 5.0, pendidikan memainkan peran penting dalam meningkatkan kualitas sumber daya manusia. Untuk menjawab tantangan era sosial tersebut, lembaga pendidikan harus mengubah paradigmanya, antara lain pendidik memperhatikan fungsi sumber belajar dan membiarkan guru fokus memberikan inspirasi kepada siswa.

Pendidikan 5.0 merupakan terobosan baru dari society 5.0 yaitu dengan cara mengintegrasikan antara manusia dan teknologi untuk dapat memanfaatkan peluang melalui cara-cara yang kreatif dan inovatif (Arjunaita, 2020). Pada perspektif pendidikan era society 5.0 ditinjau dari sudut pandang ontologi lebih menekankan pada pendidikan karakter, moral, dan keteladanan. Dikarenakan pengetahuan seseorang dapat dengan mudah dinilai dengan menggunakan teknologi, namun soft dan hard skill seseorang tidak dapat digantikan oleh teknologi. Dalam hal ini diperlukan pendidikan yang berbasis pada kemampuan memahami dan menerapkan Internet of Things (IoT), virtual atau augmented reality, serta penggunaan dan penerapan kecerdasan buatan (artificial intelligence) (Ristekdikti, 2018).

Dalam hal pendidikan, society 5.0 menuntut siswa untuk memiliki kemampuan dalam memecahkan masalah yang kompleks, berpikir kritis, dan kreativitas. Kemampuan tersebut diperlukan dalam rangka mengadopsi perkembangan ilmu pengetahuan dan teknologi, tidak hanya sebagai "taker" tetapi juga sebagai "maker" melalui prinsip-prinsip pendidikan .

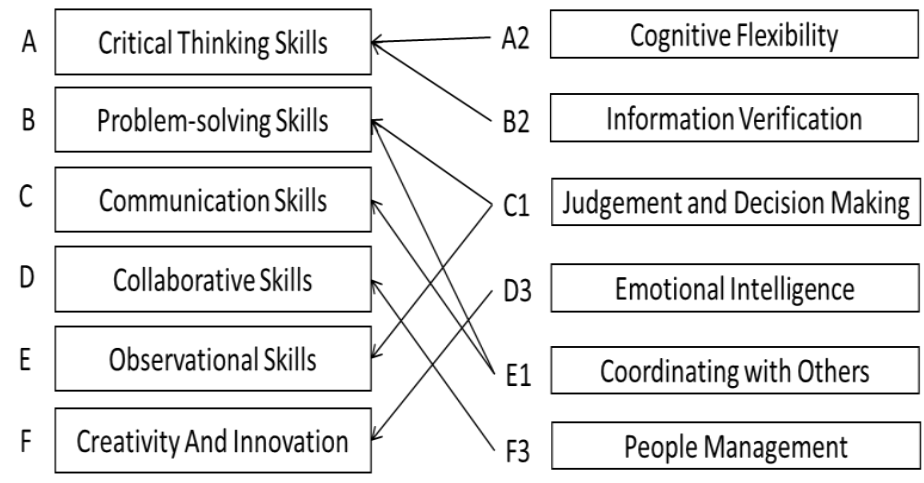

Gambar 3. Model Pembelajaran 5.0

Sumber : (Sajidan et al., 2021)

Kompetensi society 5.0 menjadi 6 indikator kompetensi akan diterapkan pada konsep pendidikan. Fleksibilitas kognitif dan indikator verifikasi informasi akan menghasilkan kompetensi keterampilan berpikir kritis; indikator penilaian dan pengambilan keputusan akan menghasilkan kompetensi keterampilan pemecahan masalah 
dan keterampilan observasional; indikator kecerdasan emosional akan menghasilkan kompetensi kreativitas dan inovasi; koordinasi dengan indikator lain akan menghasilkan kompetensi keterampilan pemecahan masalah dan keterampilan komunikasi; dan indikator manajemen orang akan menghasilkan kompetensi keterampilan kolaboratif.

Prinsip dasar era society 5.0 adalah sebagai solusi atas permasalahan yang tercipta pada era revolusi industri 4.0, antara lain permasalahan berkurangnya sosialisasi antar masyarakat, ketenagakerjaan, dan dampak internalisasi lainnya (Faruqi, 2019). Society 5.0 diharapkan mampu mensejahterakan kehidupan seluruh umat manusia. Dalam bidang pendidikan misalnya siswa mungkin dalam proses pembelajaran berhadapan langsung dengan robot-robot yang dirancang khusus atau dikendalikan oleh dosen dari jarak jauh. Proses belajar mengajar dapat terjadi dimana saja dan kapan saja, baik ada guru maupun tidak. Society 5.0 bertujuan untuk menciptakan konsep masyarakat yang peduli pada kemanusiaan, melalui pertumbuhan ekonomi dan penyelesaian masyarakat, semua tantangan diharapkan dapat diatasi, sehingga setiap fase masyarakat dapat menikmati kualitas hidup yang aktif dan nyaman (Sajidan et al., 2021).

\section{PEMBAHASAN}

Berdasarkan hasil penelitian diatas diperoleh empat komponen utama Industri 4.0: Cyber-Physical Systems, Internet of Things, Internet of Services, and Smart Factory. Sedangkan Society 5.0 merujuk pada konsep masyarakat berpusat pada manusia (humancentered) berbasis teknologi (technology based). Jika sebelumnya masyarakat informasi 4.0 yaitu mencari, mengambil dan menganalisis informasi atau data di dunia maya melalui internet. Maka pada era Society 5.0 sejumlah besar informasi yang didapat dari sensor di ruang fisik kemudian terakumulasi di dunia maya. Selain itu prioritas Society 5.0 dalam adaptasi masyarakat ke depan adalah HOTS: Higher Order Thinking Skills, jika cara berpikir yang kompleks, berjenjang, dan sistematis dapat digunakan oleh masyarakat maka inilah yang disebut dengan masyarakat 5.0 cara berpikir tingkat tinggi. Sedangkan saat ini penerapan pembelajaran masih banyak menggunakan Lower hingga Medium Order Thinking Skills (Uyun, 2021).

Industri 4.0 dan Society 5.0 mencerminkan tanggapan Jerman dan Jepang terhadap inisiatif global, dan keduanya telah diakui dunia internasional. Kedua visi tersebut mencari integrasi informasi antara industri atau sektor yang berbeda baik Industri 4.0 maupun Society 5.0 berusaha membangun arsitektur cyber global yang dapat berfungsi sebagai lingkungan yang aman untuk aktivitas kreatif. Perkembangan revolusi Industri 4.0 dan 5.0 diharapkan membawa kemajuan bagi pengembangan pendidikan khususnya di Indonesia dengan menciptakan perubahan dan menyiapkan lulusan yang unggul dan inovatif dengan skill yang sudah dipersiapkan sebelumnya. Menurut Menteri Perindustrian Airlangga Hartarto revolusi industri 4.0 dan society 5.0 membuka peluang baru untuk Indonesia. untuk berinovasi. Oleh karena itu sebagai subsistem kehidupan masyarakat, dunia 
pendidikan perlu merespon secara terbuka berbagai perubahan di dunia pendidikan yang merupakan akibat perubahan zaman baik itu 4.0 maupun 5.0 sebagai upaya untuk terus meningkatkan kualitas sumber daya manusia melalui berbagai inovasi dalam proses pembelajaran

\section{SIMPULAN}

Revolusi industri yang mengantarkan era baru revolusi industri 4.0 merupakan proses yang terus menerus mengubah tahapan otomatisasi dalam kehidupan yang bertumpu pada sistem jaringan internet. Sedangkan society 5.0 adalah masyarakat yang mampu menjawab berbagai tantangan dan masalah sosial dengan memanfaatkan berbagai inovasi yang dikembangkan selama masa revolusi industri 4.0, seperti Internet of Things (internet of everything), Artificial Intelligence (kecerdasan buatan), Big Data (data dalam jumlah besar) dan robot yang memudahkan aktivitas manusia.

Oleh karena itu kehadiran revolusi industri 4.0 dan society 5.0 mempunyai relevansi terhadap pendidikan di Indonesia. Karena baik industri 4.0 maupun Society 5.0 menekankan pada kesiapan untuk mengembangkan kreativitas dan berpikir kritis, hal ini sejalan dengan tujuan pendidikan di Indonesia. Berdasarkan hal tersebut, penulis menyimpulkan bahwa perlu dan penting bagi masyarakat untuk siap menyongsong dan melaksanakan pendidikan revolusi Industri 4.0 dan society 5.0. Cara berpikir yang harus dipahami dan digunakan adalah analitis, kritis dan kreatif untuk tetap dapat menyesuaikan dengan perkembangan zaman.

\section{PERNYATAAN PENULIS}

Penulis menyatakan bahwa artikel ini belum pernah diterbitkan dalam jurnal manapun

\section{DAFTAR PUSTAKA}

Alhefeiti, F. S. O. (2018). Society 5.0 A Human centered Society that balances economic advancement with the resolution of social problems by a system that highly integrates cyberspace and physical space. The British University in Dubai Digital Repository Dissertation for informatics Coll.

Arjunaita. (2020). Pendidikan di era revolusi industri 5.0. Prosiding Seminar Nasional Pendidikan Program Pascasarjana Universitas PGRI Palembang, 2, 179-196.

Breque, M., De Nul, L., \& Petridis, A. (2021). Industry 5.0: towards a sustainable, humancentric and resilient European industry. European Commission, Directorate-General for Research and Innovation.

Cooper, H. M. (1998). Organizing knowledge syntheses: A taxonomy of literature reviews. Knowledge in Society, 1, 104-126.

Falaq, Y. (2020). Education of Citizenship in Higher Education as A Fortress of Nation 
Characters in Facing Era Society 5.0. Journal of Educational Sciences, 4(4), 802. https://doi.org/10.31258/jes.4.4.p.802-812

Fahrezi, G., \& Susanti, S. (2021). Pengembangan Bahan Ajar Flip Book Kontekstual Berbasis Android Pada Materi Akuntansi Persediaan. Educatio, 16(1), 58-70.

Farid Ahmadi, H. I. (2020). Konsep dan aplikasi literasi baru di era revolusi industri 4.0 dan society 5.0. CV Pilar Nusantara.

Faruqi, U. A. (2019). Survey Paper : Future Service In Industry 5.0. Jurnal Sistem Cerdas, 2(1), 67-79.

Hermann, M., Pentek, T., \& Otto, B. (2015). Design Principles for Industrie 4.0 Scenarios: A Literature Review. Technische Universitat Dortmund, 1(1), 4-16. https://doi.org/10.13140/RG.2.2.29269.22248

Hitachi-UTokyo Laboratory. (2018). Society 5.0 "A People centric Super smart Society." Springer Jepang. https://doi.org/10.1007/978-981-15-2989-4

Kepa, J K., Unamuno, G., Urkia, E., Serna, A. (2019). Digital Manufacturing Platforms in the Industry 4.0 From Private and Public Perspectives. Applied Sciences.

Lu, Y., Adrados, J. S., Chand, S. S., \& Wang, L. (2021). Humans Are Not MachinesAnthropocentric Human-Machine Symbiosis for Ultra-Flexible Smart Manufacturing. Engineering, 7(6), 734-737. https://doi.org/10.1016/j.eng.2020.09.018

M. Fukuyama. (2018). Masyarakat 5.0: Bertujuan untuk Masyarakat Baru yang Berpusat pada Manusia,". In Japan SPOTLIGHT, jilid 27,. http://www8.cao.go.jp/\%0Acstp/\%0Ahttp://search.ebscohost.com/login.aspx?direct= true $\& \mathrm{db}=$ bth $\% 0 A \& A N=108487927 \&$ site $=$ ehost-live.

Pahlevi, F. S. (2016). Revitalisasi Pancasila Dalam Penegakan Hukum yang Berkeadilan di Indonesia. Justicia Islamica, 13(2).

Raharja, H. (2019). Relevansi Pancasila Era Industry 4.0 dan Society 5.0 di Pendidikan Tinggi Vokasi. Journal of Digital Education, Communication, and Arts, 2(1), 11-20. https://doi.org/DOI: 10.30871/deca.v2i1.1311

Ristekdikti. (2018). Era Revolusi Industri 4.0 Saatnya Generasi Millenial Menjadi Dosen Masa Depan. Sumber Daya IPTEK Dan DIKTI.

Sajidan, Atmojo, I. R. W., Febriansari, D., \& Suranto. (2021). A Framework of Science Based Entrepreneurship through Innovative Learning Model Toward Indonesia in Society 5.0. Journal of Physics: Conference Series, 1842(1). https://doi.org/10.1088/1742-6596/1842/1/012039

Salgues, B. (2018). Society 5.0 : Industry of the Future, Technologies, Methods and Tools. ISTE and John Wiley \& Sons. 15.

Shiroishi, Y., Uchiyama, K., Suzuki, N. (2018). Society 5.0 : For Human Security and Well-being. Computer Edisi 51, VII, 91-95.

Sumarno. (2019). Pembelajaran Kompetensi Abad 21 Menghadapi Era Society 5.0. Penguatan Pendidikan \& Kebudayaan Untuk Menyongsong Society 5.0, $272-287$. 
Uyun, S. N., \& Ali, M. (2021). Pengaruh Model Active Learning dan Kecerdasan Majemuk Logis-Matematis Terhadap Kemampuan Berpikir Kritis Siswa Pada Pembelajaran Abad 21. Educatio, 16(1), 9-23.

Vogel-Heuser, B., \& Hess, D. (2016). Guest Editorial Industry 4.0-Prerequisites and Visions. IEEE Transactions on Automation Science and Engineering, 13(2), 411-413. https://doi.org/10.1109/TASE.2016.2523639

Wegener, K., Kunz, A., Bochmann, L., \& Bänziger, T. (2016). Industrie 4.0 für den Maschinen und Anlagenbau (new academic press (ed.)).

Xu, X., Lu, Y., Vogel-Heuser, B., \& Wang, L. (2021). Industry 4.0 and Industry 5.0Inception, conception and perception. Journal of Manufacturing Systems, 61(October), 530-535. https://doi.org/10.1016/j.jmsy.2021.10.006

Yusnaini, Y. (2019). Era Revolusi Industri 4.0: Tantangan Dan Peluang Dalam Upaya Meningkatkan Literasi Pendidikan. Prosiding Seminar Nasional Program Pascasarjana Universitas Pgri Palembang.

Zuehlke, D. (2010). SmartFactory-Towards a factory-of-things. Annual Reviews in Control, 34(1), 129-138. https://doi.org/10.1016/j.arcontrol.2010.02.008 